Forest and Restoration Opportunities in the Panshet Catchment

\title{
Vegetation character and species diversity of Panshet catchment
}

\author{
Revati Gindi, Kirti Amritkar, Gunwant Mahajan, Trupti Satpute
}

Revati Gindi is an alumnus of Ecological Society, Pune and is core member of Jeevitnadi Living River Foundation, Pune. She has done field botany and advanced field botany courses conducted by Agharkar Research Institute and Nisargsevak, Pune. Presently she is working as a consultant for ecological assessment and botanical projects.

Kirti Amritkar is associated with oikos for Ecological Services, and is a core member of Jeevitnadi Living River Foundation, Pune. She is an Environment Science post graduate and an alumna of Ecological Society. She was employed as Project Officer in Maharashtra State Environment Department from 2008-2013.

Gunwant Mahajan is working as Senior Field Coordinator at Applied Environmental Research Foundation, Pune. He has done Masters in Economics and is working in the field of Environment education, research and conservation. He has worked as Research Assistant at Ecological Society, Pune.

Trupti Satpute is an Environment Science post-graduate with hands-on experience in Watershed Management, Atmospheric Sciences and Ecology. She is proficient in use of softwares like GIS and Origin for effective scientific communication. She is an alumna of Ecological Society and has worked with research institutes and NGOs as well.

\begin{abstract}
The present note elaborates the vegetation character and plant diversity in the Panshet Dam Catchment, studied during six months of field survey in 2014 (July-December) as part of a project undertaken by Ecological Society and supported by Global Forest Watch.

As floral species are directly related to climatic type, especially rainfall, therefore the Panshet catchment was divided into high, medium and low rainfall zones. The floral species survey was conducted in relation with these zones.

The focus of present study was to relate species composition with physical factors like altitude and climate. To study the vegetation character of the catchment, species level surveys of various vegetation categories like tall canopy forests, devrais, shrubbery and others, were undertaken and the species composition of each vegetation category was recorded. Moreover, species occurrence over rainfall zones was recorded. Identification of rare, endemic and specialist species was equally important to gauge the vegetation character and ecological value. Other observations included dominant species and invasive species.
\end{abstract}

\section{Study Area : Panshet Dam Catchment}

The Panshet dam is located near Panshet village at a distance of $45 \mathrm{~km}$ West of Pune city, Maharashtra, India. This dam impounds the water of river Ambi which originates in Western Ghats near a village Dapsar (Lat. N $18 \square 21 "$ Long. E 73 $\square$ 25") at an altitude of about 1200 MSL (Gole P., Tetali P., 1985).

The catchment area of 120.30 Sq. Km. encompasses a variety of land uses including village settlements, Devrais (Sacred Groves), shifting cultivation patches, dense shrubbery, scrubland, tall canopy, open grassland areas, exposed rock surfaces, riparian areas, monoculture stands, farm house schemes for urbanites, proposed townships, roads, agro industry and small industrial workshops (Ghate K., 2014). About 25 vil- lages are scattered along both the sides of reservoir.

Within the Panshet catchment there are three rainfall zones - low, medium and high with average annual rainfall of 2000 to $3000 \mathrm{~mm}, 3000$ to $6000 \mathrm{~mm}$ and 6000 to $9000 \mathrm{~mm}$ respectively (Ghate K., 2014). The rainfall drastically increases towards West of the dam as one travels towards the Western Ghats crestline.

These three rainfall zones provide different climatic conditions and create microclimates supporting specific vegetation type from moist deciduous to tropical semi-evergreen forest.

The Panshet Catchment area was studied by Ecological Society in 1985 for its status of animal and plant life with a focus on designing conservation plan 


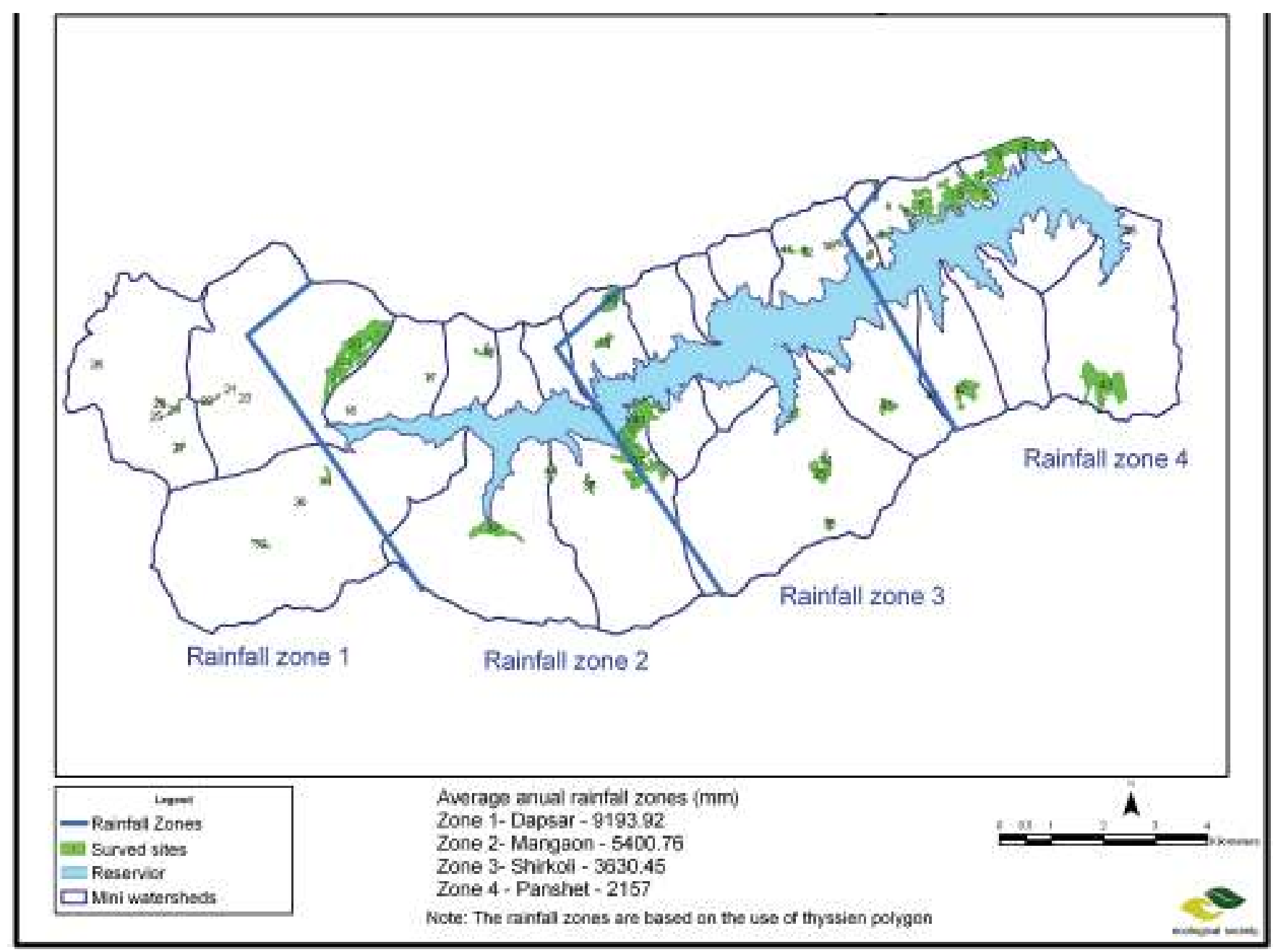

Diagram showing indicative rainfall zones in Panshet Catchment

(Ecological Society, 1985). The findings from this report about vegetation pattern and floral composition provided a baseline for the current survey.

\section{Methodology used to document floral character and species diversity}

A reconnaissance survey of the Panshet catchment was done and then sample sites were selected with the help of Google Earth images. A stratified random sampling approach was followed and 47 vegetation patches distributed across the three rainfall zones were identified for the survey (Karandikar M., Dumale V., Deshpande S., 2015). Among the 47 areas surveyed, 19 were in low rainfall zone, 15 in medium rainfall zone and 13 in high rainfall zone.

To study the flora of Panshet catchment, our team collected data about vegetation cover, species compo- sition, occurrence, regeneration etc by Line Transect method. Observation of the landscape features was the base of the documentation. For this purpose, we recorded physical factors influencing vegetation like climate, altitude, slope, substratum (soil type and depth) and habitats.

The plant species were identified using Flora of Maharashtra, Botanical Survey of India (3 volumes) and The Flora of the presidency of Bombay by Theodore Cooke. The identified plant species were categorised as per habit, endemism (in Western Ghats and India), local rarity, presence in specific habitat (specialist ${ }^{1}$ species) and IUCN (International Union for Conservation of Nature) status. The tree species were sorted as per their evergreen, deciduous and brevideciduous $^{2}$ nature while making the list. This species list was then used for further analysis. 


\section{Results and Discussion}

The results of our species level survey are described and summarized below.

1. A total of 448 plant species were recorded within the Panshet Catchment which includes 131 species of trees, 75 species of shrubs, 70 species of climbers, 143 species of herbs, 23 species of grasses and 6 species of ferns.

2. A total of 100 families and 342 genera were recorded with the highest number of plants belonging to Leguminosae family followed by Poaceae and Apocynaceae families. The maximum number of species recorded belongs to Genus Ficus i.e. 11 species, followed by Genus Acacia and Impatiens.

3. The 448 plant species recorded include 425 native and 23 non-native species. The 425 native plant species include 74 endemic, 32 specialists, 21 locally rare and 3 IUCN listed species.

4. Among the 74 species of endemic plants, 13 are endemic to Western Ghats and 4 are endemic to Northern Western Ghats.

5. Table 1 shows the species diversity categorized on the criteria of endemism, habitat specialist/ locally rare, following IUCN status. There are some striking observations regarding species peculiarity or pattern of species distribution and status of vegetation cover. The observations throw some light on the distributed ecology of the vegetation in the catchment.

6. The Panshet catchment area is broadly composed of Grasslands, Tropical moist-deciduous forest, Tropical semi-evergreen forest and Broad-leaved valley or ravine forests (Gole P., Tetali P., 1985).

7. It was observed that the low rainfall zone holds more of moist deciduous vegetation with prevalence of grasslands and degraded areas. The grassland and degraded areas are dominated with Kusali grass (Heteropogon contortus) associated with some herbaceous growth.

8. Impact of human interference is more prevalent near the dam wall. Hence, a higher level of degradation is seen in this area.

9. The high and medium rainfall zones hold tropical semi evergreen vegetation. Original tropical semi evergreen forests are seen to be relatively in good condition in sacred groves, a few riparian patches, few government forest patches and certain privately owned protected patches.

10. Some plant species were observed only in high rainfall zone, which includes tree species viz
Cassine paniculata, Diospyros sylvatica, Neolitsea zeylanica, Holigarna grahamii, Symplocos racemosa and Trichilia connaroides; Shrub species viz Abutilon persicum, Glycosmis pentaphylla, Rauvolfia verticillata and the climber Toddalia asiatica. Steep slopes in this area are dominated by Karvi (Carvia callosa).

11. In the high rainfall zone of the Panshet catchment, Kasa tree (Elaeocarpus glandulosus) is rarely found while it is seen commonly in high rainfall areas elsewhere, like Panchgani. However one huge old growth tree of this species, located in Dapsar Village (high rainfall) was observed during study.

12. Some floral species were found in both the high and medium rainfall zones. These include trees species viz Aglaia lawii, Bombax insigne, Carallia brachiata, Celtis tetrandra, Ficus nervosa, Garcinia talbotii, Litsea ghatica, Memecylon talbotianum, Persea macrantha, Sapium insigne and Tetrameles nudiflora. Shrub species of Ixora nigricans, Maytenus rothiana, Nilgirianthus heyneanus and Thelepaepale ixiocephala were found in these zones. Climbers found in these zones includes Ancistrocladus heyneanus, Caesalpinia cucullata, Gnetum scandens, Pristimera grahamii, Argyreia involucrata, Clematis gouriana, Gymnema khandalense, Hoya wightii and Piper spp.

13. In spite of heavy rainfall at the source of Ambi River, which is a crestline area of Western Ghats, comprised of cliffs and steep slopes, Euphorbia sp. was observed. It may be because of heavy rainfall causing soil erosion and physiological drought conditions on the rocky cliffs.

14. In the high rainfall area, the Ambi river hosts good riparian vegetation. The characteristics species of this zone are Umber (Ficus racemosa), Karanj (Pongamia pinnata) and Jambhul (Syzygium cumini) alongwith evergreen and brevi-deciduous tree species like Chionanthus mala-elengi, Elaeocarpus glandulosus, Ficus hispida etc.

15. Some species like Litsea ghatica, Persea macrantha, Gymnema khandalens were newly recorded as compared to the earlier survey of 1985.

16. An important highlight of this survey was the sighting of a climber, Ceropegia huberi. This is the first time it is being reported in the Panshet catchment. Its distribution is patchy and earlier it was reported only in Kolhapur (Gaganbawada), Ratnagiri (Amba Ghat), Satara (Vasota fort), and Pune (Tamhini). This species is endemic to Northern Western Ghats. 
Table 1 : List of Endemic species of Panshet Catchment with IUCN status

\begin{tabular}{|l|}
\hline Abbreviations and Terms : \\
\hline E - Evergreen, D - Deciduous \\
\hline BD - Brevideciduous \\
\hline IUCN - International Union for Conservation of Nature \\
\hline EN - Endangered; VU - Vulnerable \\
\hline NT - Near Threatened; LC - Least Concern \\
\hline $\begin{array}{l}\text { S = Specialist species - Sensitive species requiring specific habitat. Such species may disappear if habitat is } \\
\text { destroyed. }\end{array}$ \\
\hline $\mathrm{R}=$ Rare species - Species rarely found in Panshet catchment \\
\hline
\end{tabular}

\begin{tabular}{|c|c|c|c|c|c|c|}
\hline $\begin{array}{l}\text { Sr. } \\
\text { No. }\end{array}$ & Scientific name & $\begin{array}{l}\text { Local name / } \\
\text { Common name }\end{array}$ & $\begin{array}{l}\text { E/D/ } \\
\text { BD }\end{array}$ & $\mathbf{S} / \mathbf{R}$ & Endemism & $\begin{array}{l}\text { IUCN } \\
\text { Status }\end{array}$ \\
\hline & TREES & & & & & \\
\hline 1 & $\begin{array}{l}\text { Actinodaphne } \\
\text { angustifolia }\end{array}$ & Pisa & E & & Endemic to Western ghats & \\
\hline 2 & Aglaia lawii & $\ldots$ & E & & Endemic to Western ghats & \\
\hline 3 & Bombax insigne & Devsavar & $\mathrm{BD}$ & $\mathrm{R}$ & & \\
\hline 4 & Bridelia retusa & Asana & $\mathrm{BD}$ & & Endemic to India & \\
\hline 5 & Carallia brachiata & Phanshi & $\mathrm{E}$ & $\mathrm{R}$ & & \\
\hline 6 & Cassine paniculata & Bhutya (Thikra) & E & $S$ & & \\
\hline 7 & Celtis tetrandra & Brumaj & $\mathrm{BD}$ & $\mathrm{R}$ & & \\
\hline 8 & Celtis timorensis & & BD & $\mathrm{R}$ & & \\
\hline 9 & Dalbergia sissoo & Sisoo & $\mathrm{D}$ & & & VU \\
\hline 10 & Dimocarpus longan & $\mathrm{Umb}$ & E & $S$ & & \\
\hline 11 & $\begin{array}{l}\text { Dimorphocalyx } \\
\text { lawianus }\end{array}$ & Jodpakli & E & $S$ & Endemic to Western ghats & NT \\
\hline 12 & Diospyros sylvatica & & E & $S$ & & \\
\hline 13 & $\begin{array}{l}\text { Elaeocarpus } \\
\text { glandulosus }\end{array}$ & Kasa & E & $S$ & & \\
\hline 14 & Ficus nervosa & Loth & E & $S$ & & \\
\hline 15 & Flacourtia latifolia & Taambat & $\mathrm{D}$ & & Endemic to India & \\
\hline 16 & Garcinia talbotii & Phansada & $E$ & $S$ & Endemic to Western ghats & \\
\hline 17 & Glochidion ellipticum & Bhoma & E & & Endemic to Western ghats & \\
\hline 18 & Holigarna grahamii & Raan biba & $E$ & $S$ & Endemic to Western ghats & \\
\hline
\end{tabular}




\begin{tabular}{|c|c|c|c|c|c|c|}
\hline $\begin{array}{l}\text { Sr. } \\
\text { No. }\end{array}$ & Scientific name & $\begin{array}{l}\text { Local name / } \\
\text { Common name }\end{array}$ & $\begin{array}{l}\text { E/D/ } \\
\text { BD }\end{array}$ & $S / R$ & Endemism & $\begin{array}{l}\text { IUCN } \\
\text { Status }\end{array}$ \\
\hline 19 & $\begin{array}{l}\text { Hymenodictyon } \\
\text { obovatum }\end{array}$ & Kadva sirid & $\mathrm{BD}$ & & Endemic to India & \\
\hline 20 & $\begin{array}{l}\text { Lagerstroemia } \\
\text { microcarpa }\end{array}$ & Nana & $\mathrm{D}$ & & Endemic to India & \\
\hline 21 & Litsea ghatica & & E & $S$ & & \\
\hline 22 & $\begin{array}{l}\text { Mallotus } \\
\text { aureopunctatus }\end{array}$ & & E & $\mathrm{S}$ & Endemic to Western ghats & \\
\hline 23 & $\begin{array}{l}\text { Memecylon } \\
\text { talbotianum }\end{array}$ & & $\mathrm{E}$ & S & Endemic to Western ghats & \\
\hline 24 & Neolitsea zeylanica & & $\mathrm{E}$ & S & & \\
\hline 25 & Persea macrantha & Gulum & E & S & & \\
\hline 26 & $\begin{array}{l}\text { Phoenix loureiroi } \\
\text { var. pedunculatal } \\
\text { Phoenix robusta }\end{array}$ & Shelu & E & $\mathrm{R}$ & Endemic to India & \\
\hline 27 & $\begin{array}{l}\text { Sapium insigne/ } \\
\text { Falconeria insignis }\end{array}$ & Hura & $\mathrm{D}$ & & & VU \\
\hline 28 & Sterculia guttata & Kukar & $\mathrm{BD}$ & $\mathrm{R}$ & & \\
\hline 29 & Symplocos racemosa & & $\mathrm{E}$ & $S$ & & \\
\hline 30 & Terminalia paniculata & Kindal & $\mathrm{BD}$ & & Endemic to India & \\
\hline 31 & Tetrameles nudiflora & & $\mathrm{BD}$ & $\mathrm{R}$ & & \\
\hline 32 & Trichilia connaroides & Limbara & $\mathrm{E}$ & $\mathrm{R}$ & & \\
\hline \multirow[t]{2}{*}{33} & Xylia xylocarpa & Zambha & $\mathrm{D}$ & $\mathrm{R}$ & & \\
\hline & SHRUBS & & & & & \\
\hline 34 & Abutilon persicum & Madam & & $\mathrm{R}$ & & \\
\hline 35 & Agrostistachys indica & Agasti & & $\mathrm{R}$ & & \\
\hline 36 & Anisomeles heyneana & Gopali & & & Endemic to India & \\
\hline 37 & Artemisia nilagirica & Dhor Davana & & & Endemic to India & \\
\hline 38 & Cajanus lineatus & Ran tur & & & Endemic to India & \\
\hline 39 & $\begin{array}{l}\text { Calacanthus } \\
\text { grandiflorus }\end{array}$ & & & $R$ & Endemic to India & \\
\hline 40 & Capparis parviflora & Kabar & & $S$ & & \\
\hline 41 & $\begin{array}{l}\text { Carvia callosa/ } \\
\text { Strobilanthes callosus }\end{array}$ & Karwi & & & Endemic to India & \\
\hline 42 & Cissus woodrowii & Girnul & & & Endemic to India & \\
\hline 43 & Desmodium laxiflorum & Asud & & $\mathrm{R}$ & & \\
\hline
\end{tabular}




\begin{tabular}{|c|c|c|c|c|c|c|}
\hline $\begin{array}{l}\text { Sr. } \\
\text { No. }\end{array}$ & Scientific name & $\begin{array}{l}\text { Local name / } \\
\text { Common name }\end{array}$ & $\begin{array}{l}\mathrm{E} / \mathrm{D} / \\
\mathrm{BD}\end{array}$ & $\mathbf{S} / \mathbf{R}$ & Endemism & $\begin{array}{l}\text { IUCN } \\
\text { Status }\end{array}$ \\
\hline 44 & Ecbolium ligustrinum & Hirvi aboli & & $\mathrm{R}$ & & \\
\hline 45 & Glycosmis pentaphylla & $\begin{array}{l}\text { Kirmira / } \\
\text { Maenaki(Ban Limbu) }\end{array}$ & & $S$ & Endemic to India & \\
\hline 46 & Ixora brachiata & Gorbale & E & & Endemic to Western ghats & \\
\hline 47 & Ixora nigricans & & & $S$ & & \\
\hline 48 & $\begin{array}{l}\text { Maytenus rothiana/ } \\
\text { Gymnosporia rothiana }\end{array}$ & Bhalwand & & & Endemic to Western ghats & \\
\hline 49 & $\begin{array}{l}\text { Nilgirianthus } \\
\text { heyneanus }\end{array}$ & Akra & & & Endemic to India & \\
\hline 50 & Rauvolfia verticillata & Alpagandha & & $\mathrm{R}$ & & \\
\hline 51 & $\begin{array}{l}\text { Thelepaepale } \\
\text { ixiocephala }\end{array}$ & Patri & & & Endemic to India & \\
\hline \multirow[t]{2}{*}{52} & Calamus pseudotenuis & Vet & & $S$ & & \\
\hline & HERBS & & & & & \\
\hline 53 & $\begin{array}{l}\text { Adelocaryum coelestinum/ } \\
\text { Paracaryopsis coelestina }\end{array}$ & Nisurdi & & & Endemic to India & \\
\hline 54 & Aeginetia indica & & & $S$ & & \\
\hline 55 & \begin{tabular}{|l} 
Aerides crispum / \\
Aerides crispa
\end{tabular} & Panshing & & $S$ & Endemic to Western ghats & \\
\hline 56 & Aerides maculosum & & & & Endemic to peninsular India & \\
\hline 57 & Asystasia dalzelliana & Neelkanth & & & Endemic to India & \\
\hline 58 & Balanophora abbreviata & Alimbi bandgul & & $S$ & & \\
\hline 59 & Begonia crenata & Kapru & & & Endemic to India & \\
\hline 60 & Chlorophytum glaucum & & & & Endemic to India & \\
\hline 61 & Crinum latifolium & Gulabi karnaful & & $\mathrm{R}$ & & \\
\hline 62 & Crotalaria filipes var.filipes & Phatphati & & & Endemic to India & \\
\hline 63 & $\begin{array}{l}\text { Curcuma caulina / } \\
\text { Hitchenia caulina }\end{array}$ & Chavar & & $S$ & $\begin{array}{l}\text { Endemic to Northern } \\
\text { Western Ghats }\end{array}$ & \\
\hline 64 & Curcuma pseudomontana & Raanhalad & & & Endemic to India & \\
\hline 65 & $\begin{array}{l}\text { Cynarospermum } \\
\text { asperrimum }\end{array}$ & Dikna & & & Endemic to India & \\
\hline 66 & Desmodium ritchiei & & & & Endemic to India & \\
\hline 67 & Ensete superbum & Rankeli & & & Endemic to India & \\
\hline 68 & Eranthemum roseum & Dashmuli & & & Endemic to India & \\
\hline 69 & Eria dalzellii & & & $\mathrm{R}$ & Endemic to Western Ghats & \\
\hline
\end{tabular}




\begin{tabular}{|c|c|c|c|c|c|c|}
\hline $\begin{array}{l}\text { Sr. } \\
\text { No. }\end{array}$ & Scientific name & $\begin{array}{l}\text { Local name / } \\
\text { Common name }\end{array}$ & $\begin{array}{l}\mathrm{E} / \mathrm{D} / \\
\mathrm{BD}\end{array}$ & $S / R$ & Endemism & $\begin{array}{l}\text { IUCN } \\
\text { Status }\end{array}$ \\
\hline 70 & Exacum lawii & Lahan chirayat & & & Endemic to India & \\
\hline 71 & Exacum pumilum & Jambhli chirayat & & & Endemic to India & \\
\hline 72 & Geissaspis tenella & Lahan barki & & & Endemic to India & \\
\hline 73 & Habenaria grandifloriformis & & & & Endemic to Western Ghats & \\
\hline 74 & Habenaria longicorniculata & & & & $\begin{array}{l}\text { Endemic to Peninsular } \\
\text { India }\end{array}$ & \\
\hline 75 & Haplanthodes verticillatus & Jakara & & & Endemic to India & \\
\hline 76 & Hemigraphis latebrosa & Morpankhi & & & Endemic to India & \\
\hline 77 & Impatiens acaulis & & & & Endemic to India & \\
\hline 78 & Impatiens minor & & & & Endemic to India & \\
\hline 79 & Impatiens pulcherrima & Dhal - Terda & & & Endemic to India & \\
\hline 80 & Kalanchoe olivacea & Paanphuti & & & Endemic to India & \\
\hline 81 & Lavandula gibsonii & & & & Endemic to India & \\
\hline 82 & Malaxis rheedii & Mala amri & & $S$ & & \\
\hline 83 & Pecteilis gigantea & Waghchora & & S & & \\
\hline 84 & Phyllocephalum tenue & Parnagumphi & & & Endemic to India & \\
\hline 85 & Pimpinella adscendens & & & & Endemic to India & \\
\hline 86 & Pinda concanensis & Panda/Pinda & & & $\begin{array}{l}\text { Endemic to Northern } \\
\text { Western Ghats }\end{array}$ & \\
\hline 87 & $\begin{array}{l}\text { Rhamphicarpa fistulosa / } \\
\text { R. longiflora }\end{array}$ & Tutari & & & Endemic to India & \\
\hline 88 & Senecio bombayensis & Sonki & & & Endemic to India & \\
\hline 89 & Smithia bigemina & Kawla & & & Endemic to India & \\
\hline 90 & Smithia hirsuta & & & & Endemic to India & \\
\hline 91 & Smithia purpurea & Barka & & & Endemic to India & \\
\hline 92 & Swertia minor & & & & Endemic to India & \\
\hline 93 & Tectaria cicutaria & Kombadnakhi & & $\mathrm{R}$ & & \\
\hline 94 & $\begin{array}{l}\text { Trachyspermum } \\
\text { roxburghianum }\end{array}$ & Pinela & & & Endemic to India & \\
\hline \multirow[t]{2}{*}{95} & Zingiber neesanum & Nisam & & & Endemic to India & \\
\hline & CLIMBERS & & & & & \\
\hline 96 & Ancistrocladus heyneanus & Kardal & & $S$ & Endemic to India & \\
\hline 97 & $\begin{array}{l}\text { Dalbergia horrida var. } \\
\text { horrida }\end{array}$ & Pedgul & & & Endemic to India & \\
\hline
\end{tabular}




\begin{tabular}{|r|l|l|l|l|l|l|}
\hline $\begin{array}{c}\text { Sr. } \\
\text { No. }\end{array}$ & Scientific name & $\begin{array}{l}\text { Local name / } \\
\text { Common name }\end{array}$ & $\begin{array}{l}\text { E/D/ } \\
\text { BD }\end{array}$ & S/R & Endemism & $\begin{array}{l}\text { IUCN } \\
\text { Status }\end{array}$ \\
\hline 98 & Caesalpinia cucullata & Ragi & & R & & \\
\hline 99 & Gnetum scandens & Umbli & & S & & \\
\hline 100 & $\begin{array}{l}\text { Pristimera grahamii / } \\
\text { Hippocratea grahamii }\end{array}$ & Lokhandi/daushir & & S & & \\
\hline 101 & Argyreia involucrata & & & & Endemic to India & \\
\hline 102 & Argyreia sericea & Gavel & & & Endemic to India & \\
\hline 103 & Asparagus racemosus & Shatavari & & & Endemic to India & \\
\hline 104 & Ceropegia huberi & & & & $\begin{array}{l}\text { Endemic to northern } \\
\text { Western Ghats }\end{array}$ & \\
\hline 105 & Ceropegia oculata & Mor kharchudi & & & Endemic to India & \\
\hline 106 & Clematis heynei & Raanjai & & & Endemic to India & \\
\hline 107 & Cynanchum tunicatum & Panchali & & $\mathrm{R}$ & & \\
\hline 108 & Dioscorea belophylla & & & $\mathrm{R}$ & Endemic to India & \\
\hline 109 & Entada rheedii & Garambi & & $\mathrm{S}$ & & \\
\hline 110 & $\begin{array}{l}\text { Gymnema khandalense/ } \\
\text { Bidaria khandalense }\end{array}$ & & & $\mathrm{S}$ & $\begin{array}{l}\text { Endemic to Northern } \\
\text { Western Ghats }\end{array}$ & \\
\hline 111 & Hoya wightii & Ambari & & S & Endemic to India & \\
\hline 112 & Jasminum malabaricum & Kusar & & & Endemic to India & \\
\hline 113 & Piper spp. & Jungli mirchi & & S & & \\
\hline 114 & Toddalia asiatica & & & \\
\hline
\end{tabular}

Note: Above list is a result of 6 months survey and more species may get recorded with a detailed multi-season survey.

Table 2 : Floral composition observed in rainfall zones

\begin{tabular}{|l|l|l|}
\hline Rainfall Zone & Average annual rainfall & Floral Composition \\
\hline Low & 2000 to $3000 \mathrm{~mm}$ & Terminalia- Bridelia - Mangifera \\
\hline Medium & 3000 to $6000 \mathrm{~mm}$ & Actinodaphne -Terminalia- Albizia \\
\hline High & 6000 to $9000 \mathrm{~mm}$ & Memecylon- Olea- Syzygium \\
\hline
\end{tabular}

Note: This composition is as per the data collection and observations done by the team in catchment. Quadrat sampling was not done. 
Table 3- Distribution of sacred groves in rainfall zones

\begin{tabular}{|l|l|l|}
\hline Low rainfall zone & Medium rainfall Zone & High Rainfall Zone \\
\hline 1. Viroba SG, Ambegaon & 1. Vardaini SG, Gondekhal & 1. Unnamed SG, Kurtawadi \\
2. Bhairi SG, Ambegaon & 2. Somjai SG, Gondekhal & 2. Vardaini SG, Kurtawadi \\
3. Talawati SG, Ambegaon & 3. Janani SG, Mangaon & 3. Jakhin and Kalkai SG, Dapsar \\
4. Pandharphali SG, Vanjarwadi & 4. Shirkai SG, Shirkoli & 4. Kuthar SG, Dapsar \\
5. Kalkai SG, Vanjarwadi & & 5. Shambhoji SG, Dapsar \\
6. Kalkai SG, Giwashi & & 6. Somjai SG, Dapsar \\
7. Jagoba SG, Giwashi & & 7. Mulai SG, Dapsar \\
& & 8. Kalkai SG, Tekpovale \\
& & 9. Vardaini SG, Tekpovale \\
\hline
\end{tabular}

Note: SG - Sacred Grove

17. The whole catchment area is dotted with sacred groves. They differ in size. The highest number of sacred groves was observed in high rainfall zone. The Mangaon Sacred Grove in medium rainfall zone is the largest sacred grove with an area of about 16 ha. (Table 3)

18. People cultivate Dendrocalamus species of Bamboo around their villages for economic reasons (Gole P., Tetali P., 1985). A naturally growing bamboo species, Kalak (Bambusa arundinacea) was observed in the high rainfall zone.

19. Inspite of the timber value, the locals preserved mango trees since the fruits offer sustainable income for them. Due to this, the dominant vegetation in the low and medium rainfall zones consists of mango trees.

20. In the high rainfall zone, one of the characteristic components of vegetation is Lianas. Species like Umbali (Gnetum scandens), Kardal (Ancistrocladus heyneanus), Watoli (Diploclisia glaucescens), along with Garambi (Entada rheedii) were found in good canopy patches.

21. Liana of Garambi (Entada rheedii) is found throughout the catchment. In the low rainfall zone, it is found only in sacred groves, probably because of suitable conditions of moisture. In the high rainfall zone, it is more common and found even along the roads, covering trees and creating dense canopy.

22. Relative to 1985 , shifting cultivation practices have now declined. The abandoned shifting cultivation patches are now covered with dense shrubbery and show growth of woody and hardy species like Karwand (Carissa congesta), Dhayati (Woodfordia fruticosa) along with tree species like
Ain (Terminalia tomentosa), Kumbha (Careya arborea), Asana (Bridelia retusa) etc. Good regeneration of plant species was observed in all three rainfall zones.

23. Plantations of non-native species like Gliricidia and Australian Acacia were observed on large scale in the vicinity of the dam wall, near the reservoir and on hill slopes throughout the catchment.

24. Wild vegetation provides food for local people e.g. Kartoli (Momordica dioica), Takala (Cassia tora), Kurdu (Celosia argentea) and fruits of Karvanda (Carissa congesta), Alu (Meyna laxiflora), Mango (Mangifera indica) etc.

25. Presence of weeds was very common along the roads, fringe areas of sacred groves, open areas, periphery of agricultural land and settlements. Invasive species like Cosmos, Eupatorium, Parthenium, Alternanthera, Lantana etc. were found throughout the catchment.

\section{Conclusions}

1. The occurrence of some specialist plants in dense vegetation patches outside sacred groves highlights the need of conserving these vegetation patches for conservation of catchment area vegetation and maintaining habitat continuity in the area.

2. The sacred groves harbor higher number of specialist and endemic species and need to be conserved with high priority.

3. Even in the low rainfall zone, if protection is provided, species like Ceropegia bulbosa and Ceropegia oculata are seen regenerating. This observation was made in the plot where Ecological 
Representative Photographs of Survey areas and plant species

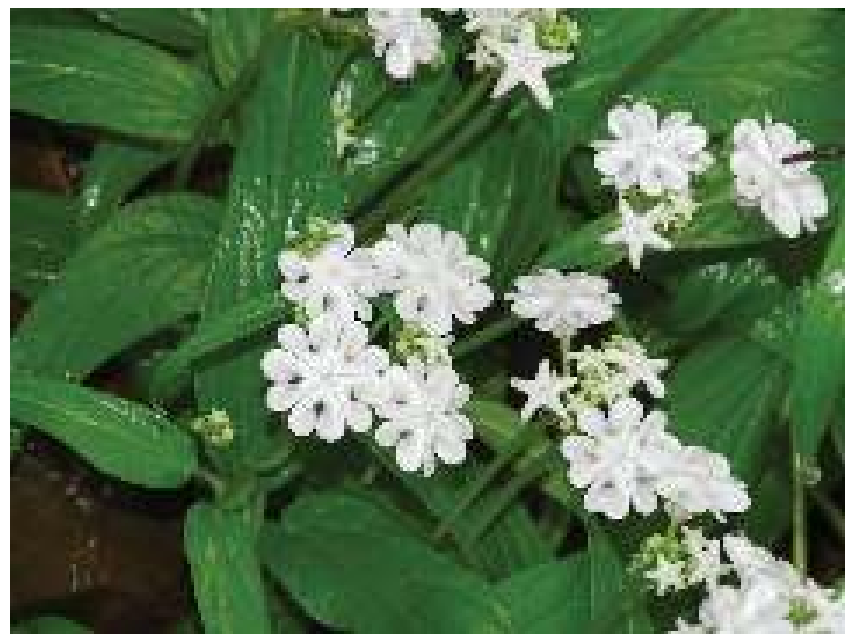

Ceropegia huberi, climber endemic to Northern Western Ghats

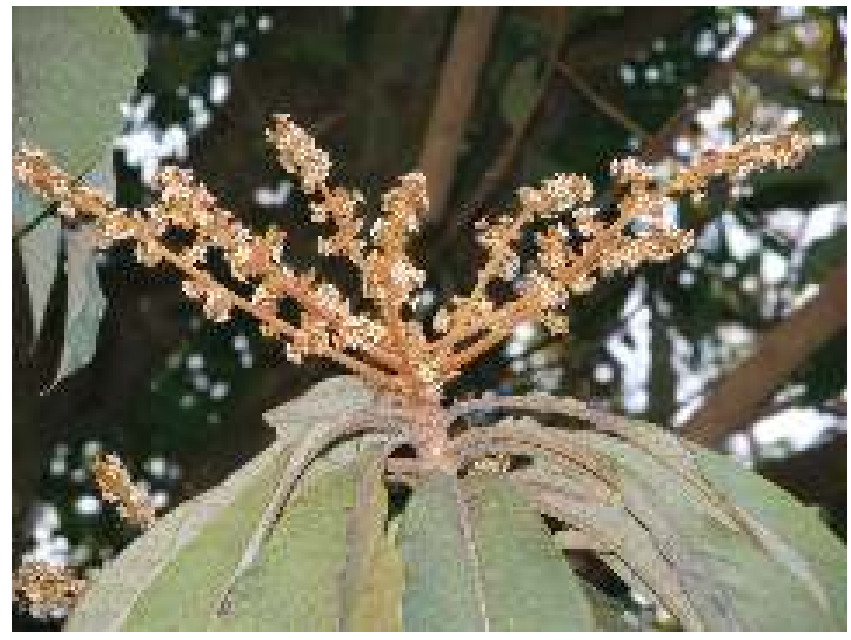

Holigarna grahamii (Ran bibba), tree found only in high rainfall zone

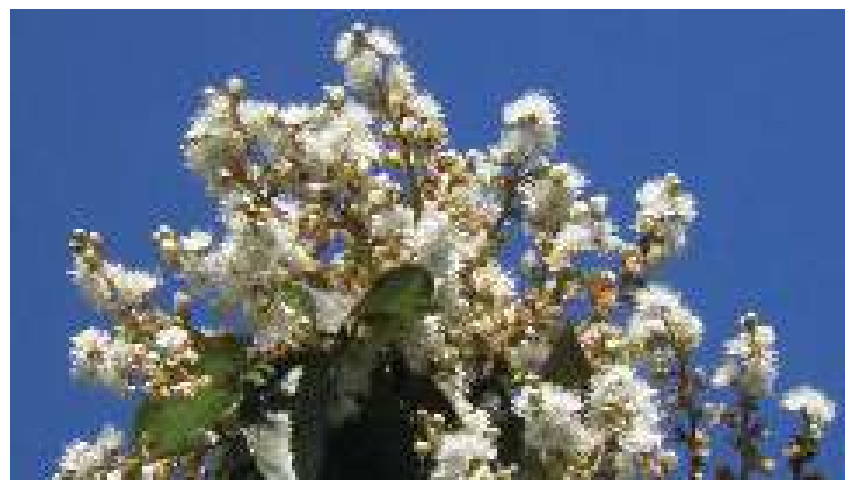

Symplocos racemosa, tree found only in high rainfall zone

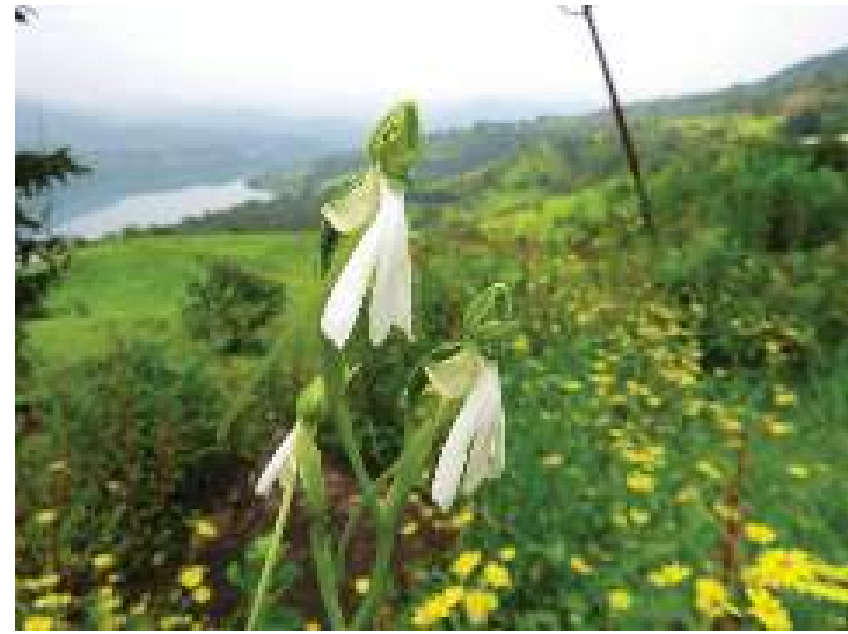

Habenaria longicorniculata

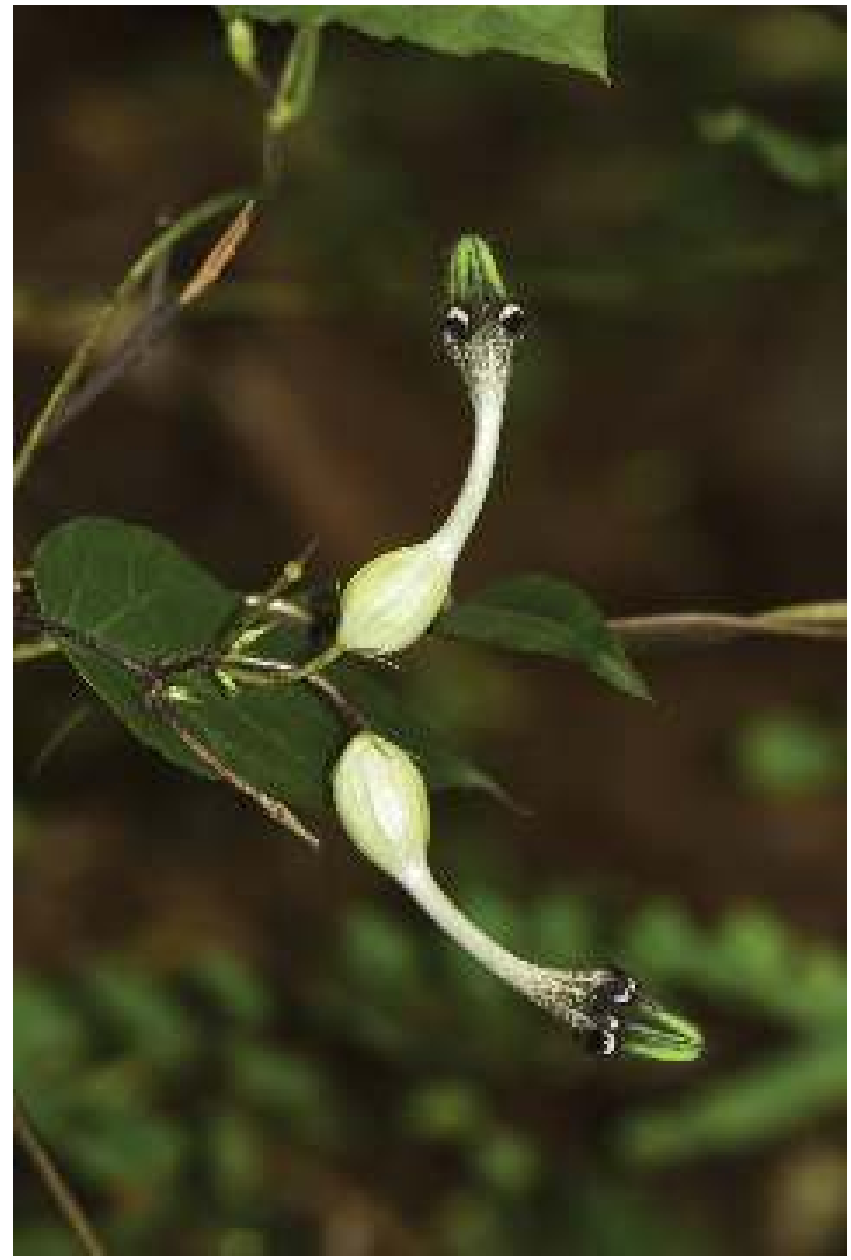

Ceropegia occulata 


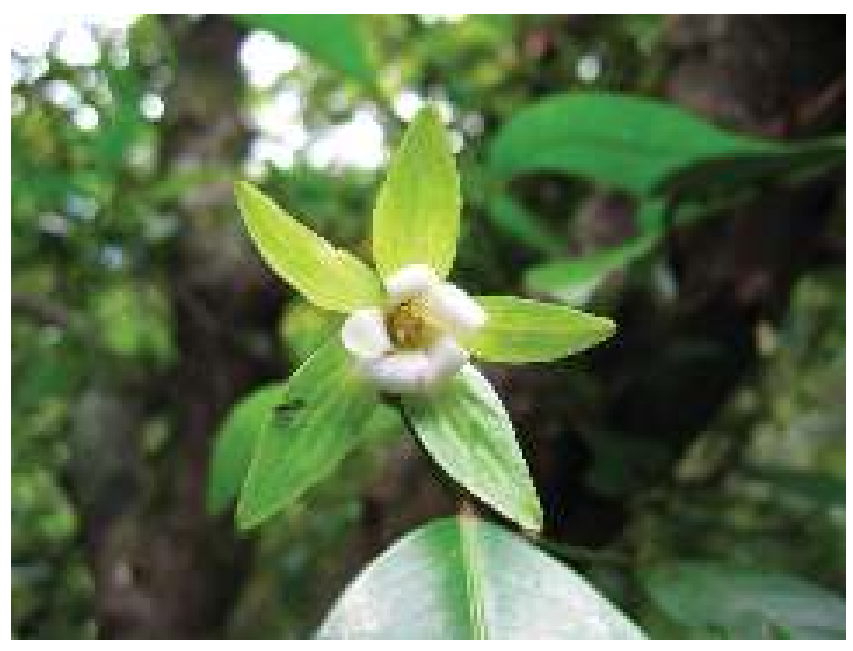

Dimorphocalyx lawianus (Jodpakali), tree endemic to Western Ghats

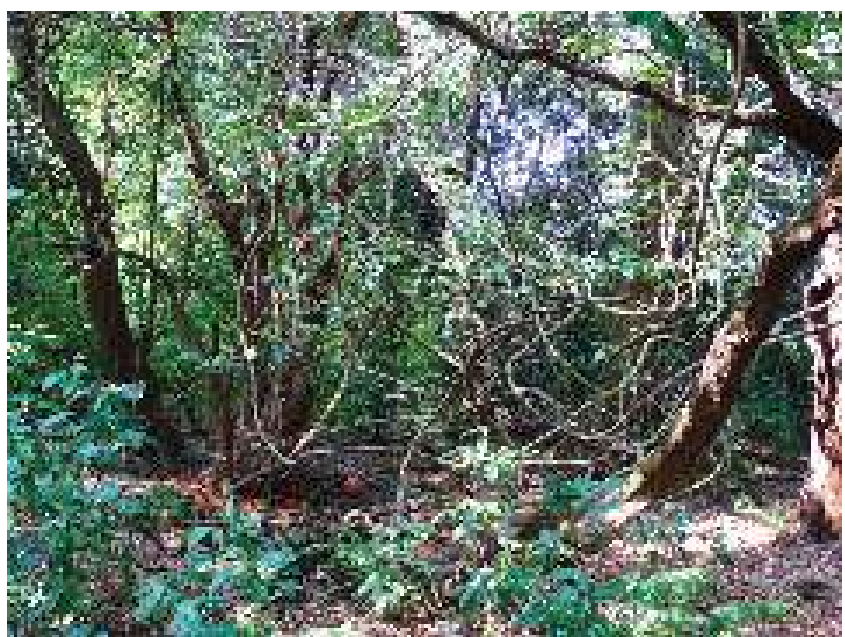

Kuthar sacred grove

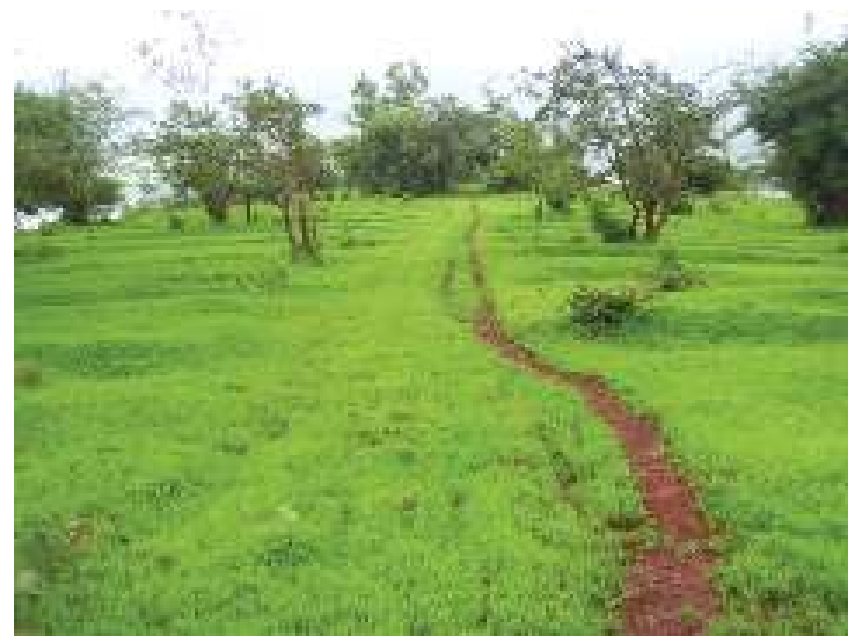

Open grassland in Ambegaon Khurd village

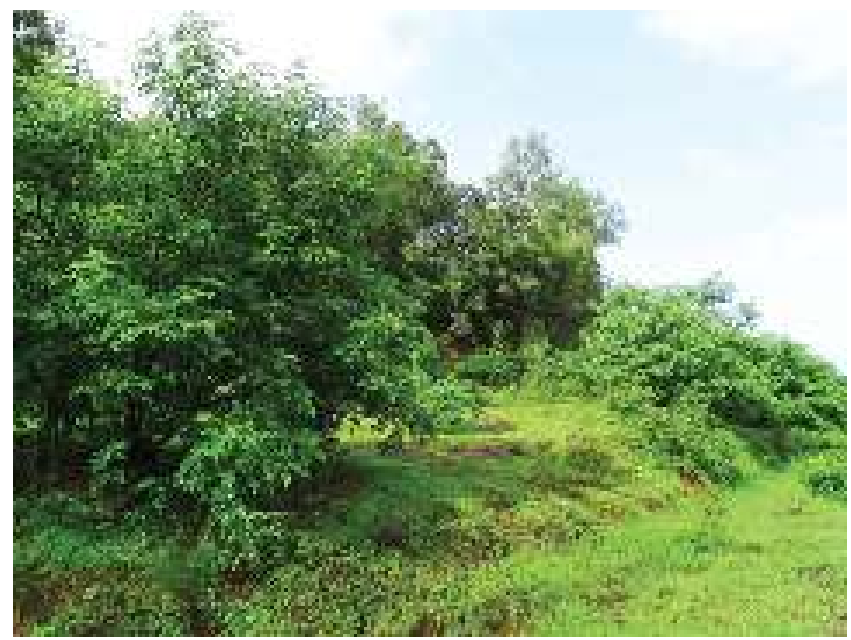

Shrubbery

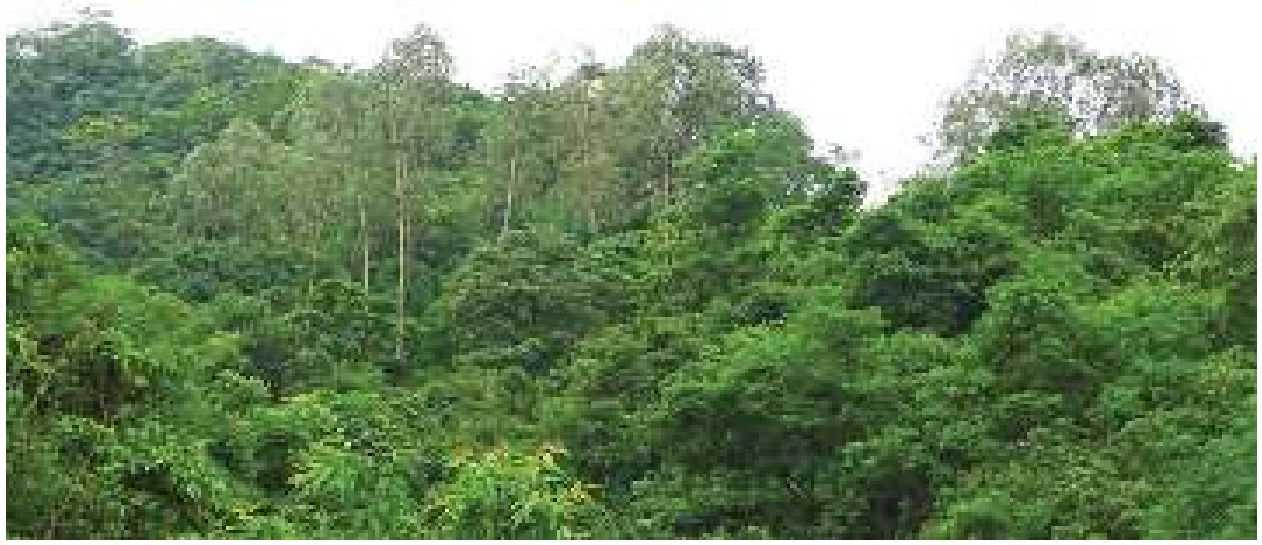

Tall canopy 
Society has carried out ecological restoration for the past several years.

4. The previous ecological survey of Ecological Society pertaining to the Panshet catchment dates back to 1985 i.e. more than 30 years ago. The present detailed survey was conducted in 2014, though only for six months; therefore the extensive survey and further studies of the vegetation in Panshet catchment are needed.

5. Looking at the vegetation composition of mature forest including sacred groves, high endemism was observed in the high rainfall zone near crestline. Several streams and river Ambi originate in this area. Therefore this area has a high conservation value.

6. There is an urgent need to protect the following rare and specialist species otherwise they will become locally extinct due to continued degradation and land use change: Ancistrocladus heyneanus, Ceropegia huberi, Elaeocarpus glandulosus, Garcinia talbotii, Cassine paniculata etc.

7. The association between flora and fauna highlights the importance of preserving various types of forests. e.g. The Malabar Giant Squirrel is associated with continuous canopy seen in sacred groves.

8. There are several threats to sacred groves like cattle grazing, tree cutting, transport through grove, temple construction inside the grove, road construction, presence of adjacent private land and construction projects coming up in vicinity etc. Sacred groves being old mature forests of great biological value, these issues must be prioritised.

\section{References}

An Enquiry into the Status of animal and plant life in critical areas of Western Ghats in order to evolve plan to conserve their biological diversity, Ecological Society, Pune, Vol I and II, 1985.
Report of Ecological Survey undertaken in Panshet Catchment and Bhimashankar Wildlife Sanctuary under Small Grants Program, Global Forest Watch, Ecological Society, Pune, India, April 10, 2015.

The Sacred Groves of Western Ghats in India, Gadgil M. and Vartak V., Economic Botany, 1976.

Changes in Ecological Landscape Pattern and Land Use from 1985 to 2014 in the Panshet Dam Catchment, Karandikar M., Dumale V., Deshpande S., Journal of Ecological Society, Volume 28, 2015.

Management of Forests in Northern Western Ghats, Ghate K., Journal of Ecological Society, Volume 26 27, 2014.

Flora of Maharashtra State (Dicotyledones), Volume 1, Editors N.P.Singh, S. Karthikeyan, P. Lakshminarasimhan and P. V. Prasanna, Botanical Survey of India, 2000

Flora of Maharashtra State (Dicotyledones), Volume 2, Editors N.P.Singh, P. Lakshminarasimhan, S. Karthikeyan and P. V. Prasanna, Botanical Survey of India, 2001

Endemic and Threatened Flowering Plants of Maharashtra, Dipak Kumar Mishra and N. P. Singh, Botanical Survey of India, 2001

The IUCN Red List of Threatened Species. Version 2014.3. <www.iucnredlist.org>. Downloaded on 31 January 2015.)

http://wgbis.ces.iisc.ernet.in/biodiversity / database_new $/$ ?q=node $/ 35$

http://www.ifpindia.org/content/mapping-tree-endemism-western-ghats

\section{Endnotes}

1. Specialist species is a species having specific habitat requirement and it occurs as remnant of original (primary) forest, whereas generalist species can occupy a variety of habitats including degraded.

2. Brevideciduous trees show brief loss of leaves just prior to flowering or before new leaf growth. 